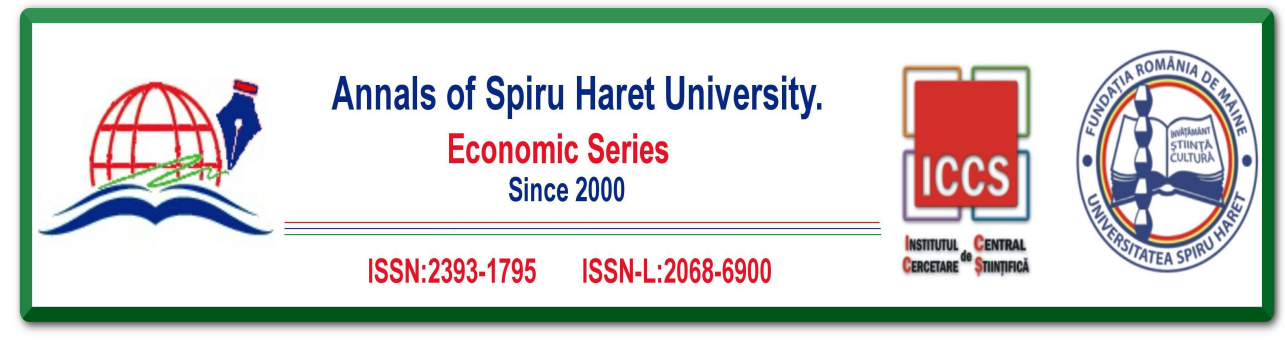

Issue 2/2019

\title{
A REVIEW OF EMPLOYEES' JOB SATISFACTION AND ITS AFFECT ON THEIR RETENTION
}

\author{
Ikechukwu Emmanuel IRABOR ${ }^{1}$, Ugo Chuks OKOLIE ${ }^{2}$ \\ ${ }^{1}$ Agho Clinic, Benin City, Edo State, Nigeria, Telephone: \\ +2348056423596, Email: iccoba97@yahoo.com \\ ${ }^{2}$ Chartered Institute of Personnel Management of Nigeria \\ Edo State Study Centre, Benin City, Telephone: 08063499170 , \\ Email: ugookolie3@gmail.com
}

How to cite: IRABOR, I. E. \& OKOLIE, U. C. (2019). "A Review of Employees' Job Satisfaction and Its Affect on Their Retention." Annals of Spiru Haret University. Economic Series, 19(2), 93-114, doi: https://doi.org/ $10.26458 / 1924$

\begin{abstract}
Learning about factors that influence staff retention and ways of improving it can help organizations avoid the inconvenience of high attrition. The employee's job satisfaction and retention are the main factors for the success and survival of any firm. No one can measure the level of satisfaction an individual gets while he performs his work. But there are factors which directly or indirectly affect the satisfaction level of employees at workplace. Companies that build work environments that attract, motivate, and retain talented employees will be better positioned to succeed in today's competitive business world that demands quality and cost-efficiency. The main challenges that organizations are facing today is not only managing its human resources but also satisfying and retaining them. Securing and retaining skilled workforce play an important role for any organization, because the knowledge and skills of employees have become highly essential in gaining competitive advantage in today's business environment. Thus, the objective of this paper was to: examine the factors which affect the job satisfaction of employees. Determine the affect of job satisfaction on employees' retention and suggest recommendations on possible ways to improve employees' retention. Also, the
\end{abstract}




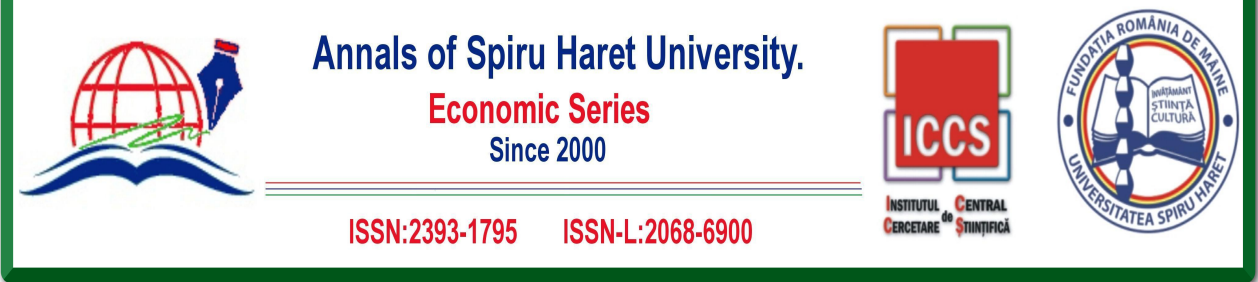

Issue 2/2019

essential of having a retention strategy, which is based on a well enunciated human resource management system, was emphasized.

Keywords: job satisfaction; employee retention; impact; turnover; human resource management.

\section{JEL Classification: T2}

\section{Introduction}

Employees are the life-blood of any business establishment. Even though virtually all organization are nowadays technologically driven in modern business management, human resources are still relevant and most desirable resources of the organization [Anyim, Ikemefuna \& Mbah, 2011; Das \& Baruah, 2013; Khan \& Aleem, 2014; Nabi, Atimed \& Rahman, 2017]. The essential values of human resources stem from the fact that, apart from other resources employed in the course of production (Land, capital, technology etc.) which are passive, employees are endowed with discretionary decision-making powers and thus have competitive advantage over the other resources. Therefore, they are the most highly important and active resources of an organization. This supports the assertion of Stein (2000) who posits that human resources are highly important for organizational excellence and they act as the key factor for achieving expected organizational goals.

Job satisfaction depicts how contented an employee is with his or her job. It is the sum of pleasure or contentment associated with a job. Job satisfaction is a part of life satisfaction. It is an emotional response to a job [Parvin \& Kabir, 2011; Singh \& Jain, 2013]. Employee satisfaction is one of the most importantly and widely researched topics in the field of organization psychology [Spector, 1997]. Job satisfaction has been studied both as a consequence of many individual and work environment characteristics and as an antecedent to many outcomes [Lease, 1998; Ruchi \& Surinder, 2014]. Therefore, individuals who have higher job satisfaction are usually less absent, less likely to leave, more generative, more likely to display organizational loyalty, and more likely to be gratified with their lives [Lease, 1998; Osteraker, 1999; Hytter, 2007; Armstrong, 2009; Robbins, judge \& Sanghi, 2009; Bateman \& Snell, 2011; Singh \& Jain, 2013; Elnaga \& Imran, 2014; Nabi et al., 2017; Okolie \& Omole, 2017]. There are various factors that can affect an individual's level of job 


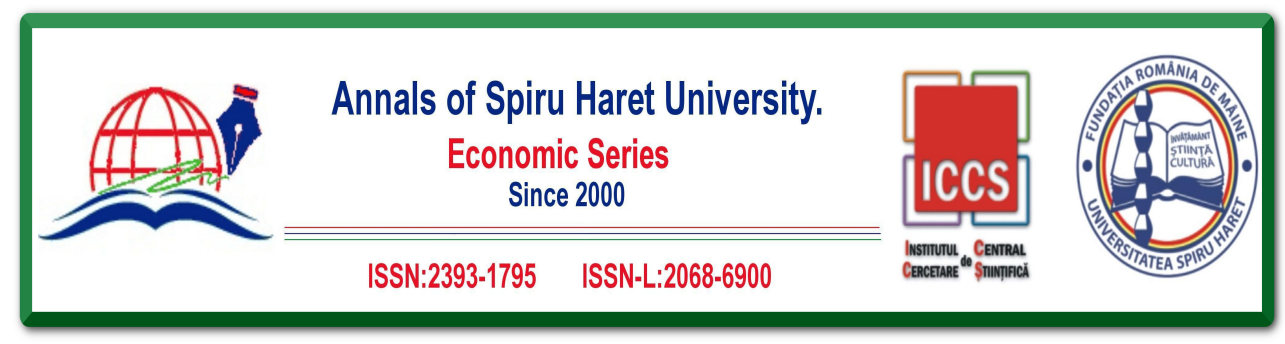

Issue 2/2019

satisfaction. Some of these factors include the level of pay and benefits; the quality of the working conditions; the job itself (the various tasks involved, the interest and demand the job generates, and the clarity of the job description/requirements); the perceived fairness of the promotion arrangement within an organization; and the leadership and social relationships [Parvin \& Kabir, 2011].

Employee retention, on the other hand, has been viewed as a responsibility to continue to do business or exchange with a particular organization on an ongoing basis [Zeineldin, 2000]. Attracting and retaining talented workforce play an essential role for any organization, because employees' knowledge and skills are central to companies' ability to be economically competitive. However, in a competitive business world, the retention of skilled employees is very hard to do. Top management and HR department put in an extensive time, financial resources and effort in order to keep their employees and obtain competitive advantage [Barlett \& Ghoshal, 2013]. Encouraging employees to stay in the organization for an extensive long period of time is increasingly viewed as a 'win-win' strategy for employers and employees. Studies have shown that retention is determined by quite a few key factors, which need to be managed congruently. These factors are positive work environment, opportunities for personal and professional growth, compelling future and financial rewards [Adegoke, 2013; Dutta \& Banerjee, 2014; Haider et al., 2015]. Employee's turnover in the changing and highly competitive environment is on the increase in most organizations in the world today. Employee turnover is a major challenge for many organizations. It is becoming a serious problem which costs a lot of money, efforts and energy. This problem might be a major obstacle for HR professionals in the formulation of their HR policies. Employee attrition also ruins the customer confidence in the organization as many customers don't want to teach about their needs to the new employees [Shakeel \& But, 2015]. So, it is better to keep employees that can retain customers.

The purpose of this paper was to examine the factors which determine the job satisfaction of employees; determine the affect of job satisfaction on employees' retention and propose recommendations on possible ways to improve employee retention. Also, the importance of having a retention strategy, which is based on a well articulated human resource management system, was emphasized.

\section{Concept of Job Satisfaction}

Employees' job satisfaction refers to the contentment experienced by an employee out of his/her job. It is an irrefutable feeling about one's job, resulting from the 


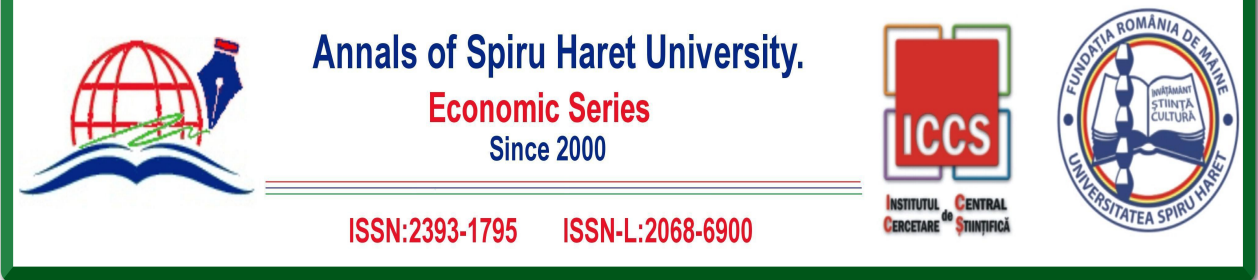

Issue 2/2019

valuation of its characteristics [Robbins et al., 2009]. Job satisfaction represents an attitude rather than a behaviour. The study of employee's job satisfaction is a topic of wide interest to both individuals who work in organizations and individuals who study them. Job satisfaction has been closely related with many organizational phenomena such as motivation, performance, attitude, leadership, morale etc. Researchers such as Ohadinma (2005); Umukoro (2005); Parvin and Kabir (2011); Singh and Jain (2013); Kahan and Aleem 92014); Okolie, Ighorhiohwunu and Omole (2017) have successfully identified the diverse elements of job satisfaction, measured the relative importance of each element of job satisfaction and examined what effects that components have on employees' productivity.

Umukoro (2005:49) defined job satisfaction as "the feeling of contentment experienced by someone whose performance has been recognized through performance appraisal as commensurate with what is expected of him". This feeling makes the individual to have a favourable disposition towards his job. The employee's source of satisfaction is his perception that his performance is recognized as satisfactory. Job satisfaction is also dependent on how the job provides those things that the individual desires. Therefore, the employee whose job is recognized as satisfactory after performance appraisal will be very happy if it is accompanied with favourable outcomes such as pay and advancement, job security, and praise. Ellickson and Logsdon (2002) support this view by defining job satisfaction as the degree to which people like their work. Reilly (1991) sees job satisfaction as the feeling that a worker has about his job or a general attitude towards work or a job and it is influenced by the perception of one's job. Unugbro (2006) stated that job satisfaction is an effective response towards various facet of an employee's work. Wanous and Lawler (1972) posited that job satisfaction expresses the amount of congruence between one's expectations of the job and the rewards that the job provides. Job satisfaction is ever-changing and must therefore be asseverated at all times.

Job dissatisfaction and satisfaction not only depend on the nature of the job, they also depend on the expectations that the job provides. Beateman and Snell (2011) posit that if the employees feel properly treated for the results they have or for the processes they use, they will be satisfied. A satisfied worker is not necessarily more productive than a dissatisfied one; sometimes workers are happy with their jobs because they don't have to work hard. But job dissatisfaction, aggregated across many individuals, creates a workforce that is more likely to exhibits (i) higher 96 


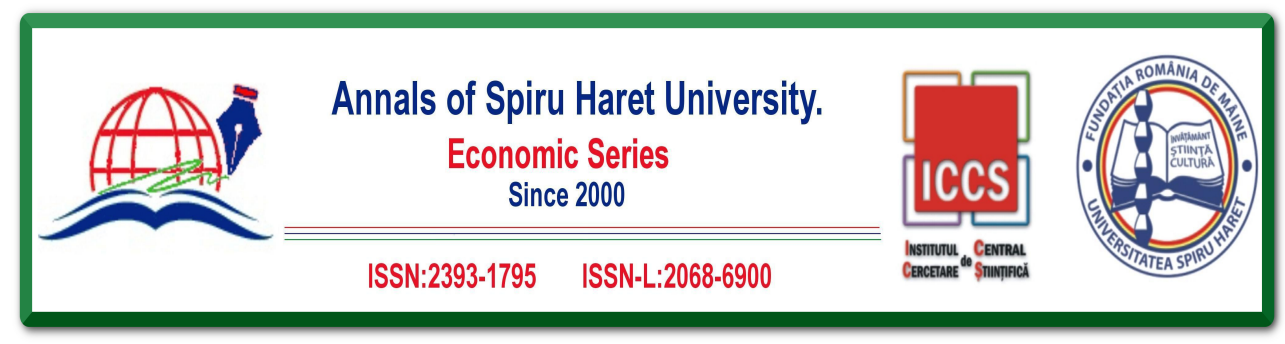

Issue 2/2019

turnover, (ii) higher absenteeism; (iii) less good citizenship among employees; (iv) more grievances and lawsuits; (v) strikes; (vi) stealing, sabotage, and vandalism; (vii) poor mental and physical health (which could lead to higher job stress, higher insurance costs, and more lawsuits); (viii) poor customer service; (ix) more injuries; (x) lower productivity and profits [Bateman \& Snell, 2011; Safdar, 2012; Khan \& Aleem, 2014; Ruchi \& Surinder, 2014]. Job satisfaction is a complex phenomenon with multi-facets and influenced by factors such as pay and promotion, working environment, communication, autonomy, and organizational loyalty [Mulinge \& Muller, 1998; Vidal, Valle \& Aragon, 2007; Lane, Esser, Holte \& McCusker, 2010; Parvin \& Kabir, 2011]. However, factors that could enhance job satisfaction in developing countries especially Nigeria include: (i) good salary; (ii) regular payment of salaries; (iii) beautiful fringe benefits; (iv) conducive work environment; (v) quality leadership and social relationships; (vi) the perceived fairness of promotion system within an organization. These factors are inducement that will produce the feeling of contentment, fulfilment, and happiness, which are the hallmark of job satisfaction.

\section{Determinants of Employees' Job Satisfaction}

Employees' job satisfaction is not determined by a single factor only. Gone are the days when one would conclude that a match between the job attributes and the employees' needs was the answer to job satisfaction. Recent research studies on the issue revealed that the determinants of job satisfaction are more complicated than this. Thus, in addition to the above, other variables still determine job satisfaction. These variables according to Ohadinma (2005); Unugbro (2006); Robbins et al. (2009), including the following:

(1) Expectations: The expectations of an employee from the job is an important determining factor. For instance, where he/she expected the job to be challenging and it is not, he/she is likely to be dissatisfied. But if he/she had expected it to be dull and it turned out to be so, his/her frustrations however might be minimal.

(2) Self-evaluation: An employee's self-concept is another determinant of job satisfaction. Where he/she sees himself/herself as one who is generally satisfied or can cope well, he/she will be unwilling to admit that a job can get him down, but if he/she has the sunny type of disposition, this is likely to reflect on his/her attitude towards the job.

(3) Input/output Relations: An employee's satisfaction on his/her job also depends on how he/she perceives the relationship between what he/she brings into 


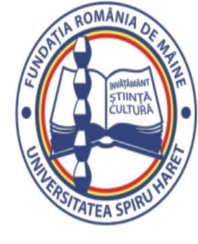

Issue 2/2019

the job (input) and what he/she gets out of it (output). Thus, if he/she fails to accomplish his/her desired output despite his/her hard-work (input), he/she will be less satisfied than if he/she had merely put in a half-hearted effort.

(4) Social Norms and Comparisons: The values other people (Particularly opinion leaders) in the society place on jobs also influence job satisfaction. When they see the job as good and important, their morale on the job will be high and hence their satisfaction. Also, where one's peers have more challenging jobs than he/she does, he/she is likely to be less satisfied than if all of them were on the same boat.

(5) Priming: The type of primary emphasis being laid on the job also is an attribute of job satisfaction. For instance, if pay package is the emphasis amongst one's peers, the employee is likely to think it is important, but if his/her organization publicize job enrichment rather, he/she is most likely to be upset when the much acclaimed programme (job enrichment) fails to live up to its credit.

\section{Benefits of Employees'Job Satisfaction}

Employees' job satisfaction is increasingly viewed as a 'win-win' strategy for employers and employees. Ejiogu (1978) concluded that job satisfaction gives top management an indication of the general levels of satisfaction in the organization. It brings about improved attitude, useful in determining certain training needs. Other benefits include increased productivity, reduced absenteeism, reduced sick leave usage, meliorated recruitment and retention rates with associated cost savings, and a diminution in workers stress and employees' loyalty, etc.

\section{Benefits for the Employer}

(i) Increased productivity.

(ii) Reduced turnover, recruiting, and training costs.

(iii) Heightened organizational effectiveness and flexibility.

(iv) Reduced absenteeism.

(v) Enhanced customer satisfaction and loyalty.

(vi) Enhanced employee retention.

(vii) Improved teamwork.

(viii) Reduced accidents, wastages and breakages.

(ix) Improved corporate image.

Benefits for the Employee

(1) Improved employee morale and loyalty. 


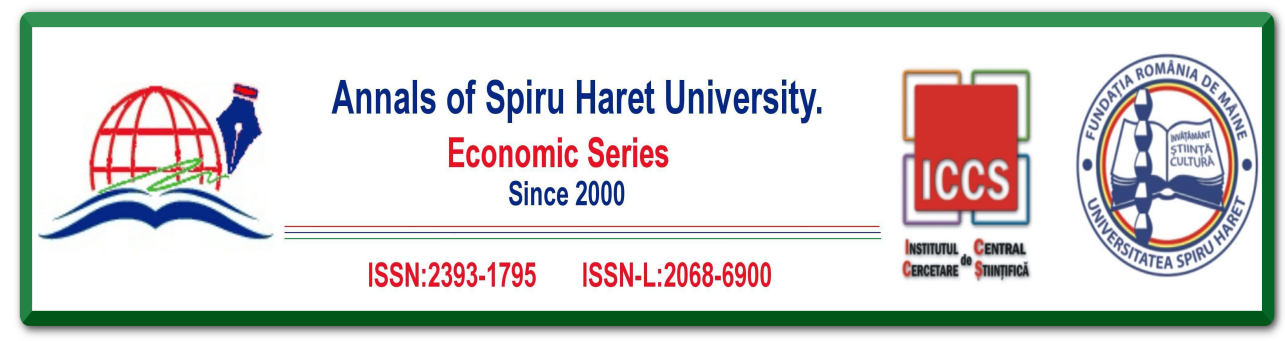

Issue 2/2019

(2) Enhanced employee commitment to the organization.

(3) Motivated employees towards exceptional performance.

(4) Reduced workers stress.

(5) Employees' work is more productive.

(6) Improved employees' happiness and self-esteem.

(7) Improved employees' health, concentration, and confidence.

(8) Opportunities for work-life balance.

(9) Improved employees' relations with management and customers.

\section{Factors Influencing Employees'Job Satisfaction}

Robbins et al. (2009); Parvin and Kabir (2011); Singh and Jain (2013); Ruchi and Surinder (2014); Nabi et al. (2017) recognised that employees' job satisfaction is not influenced by a single factor, but there are hosts of factors such as pay, promotion, training and development, working conditions, leadership styles, relationship with superior authority, job security, relationship with the group members, fairness, nature of the job itself. Together, these factors suggest a set of workplace norms and practices that might be taken as inviting employees' job satisfaction and therefore staff retention. For the objective of this paper, the following factors affecting employees' job satisfaction were examined as shown below:

\section{Working Conditions}

Employees will be more satisfied with their jobs if the environment where the job is done is conductive. An unconductive working condition will not likely contribute to satisfaction. Workforce is highly motivated with good working condition as they provide a feeling of safety, comfort and motivation. On the other hand, poor working conditions bring about fear of bad health in employees. According to Miller, Erickson and Yust (2001), employees get benefited by workplace that provides the sense of belonging. Wells and Thelen (2005) stated in their study that organization which have generous human resource policies have a very good chance to satisfy and retain employees by providing them an appropriate level of privacy and sound control on work environment which enhances the motivation levels to commit with the organization for the long-term. The following points may be delineated under this category:

(i) Feeling safe and comfort in working environment.

(ii) Safety tools and equipment. 


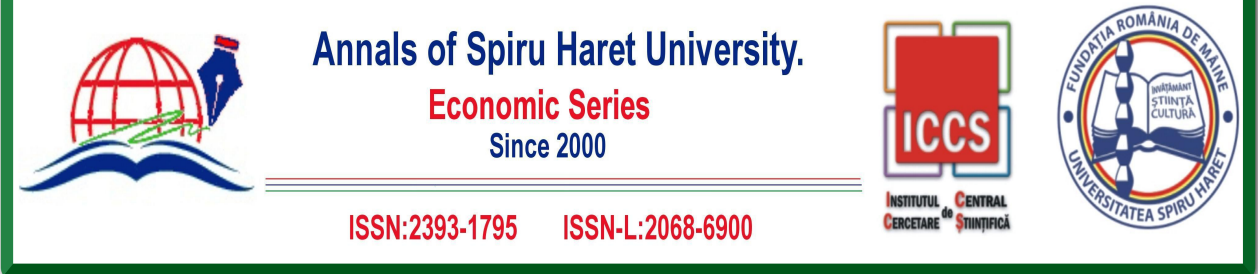

Issue 2/2019

(iii) Security guards and parking facility

(iv) Neat and clean office place, washrooms, and rest room.

(v) Well ventilated with light, fans, and air conditioning.

(vi) Safe working methods.

\section{Pay and Promotion}

Pay is the most essential variable for employee's job satisfaction. In the view of Silbert (2005), pay (reward) is essential because it has an enduring impression on employees which, in turn, gives the employees an impression that they are valued in the organization. Promotion, on the other hand, involves moving an employee to a job involving higher pay; more responsibility, authority, and independence; and higher status. Rewarding hardworking individuals through promotion will more likely contribute to their satisfaction. However, promotional opportunities accompanied with increase in financial rewards usually have more force or determine the amount of satisfaction to the employee. The following points may be considered under this category:

(i) Opportunity for promotion.

(ii) Wages or salaries.

(iii) Incentives such medical allowance, education allowance, etc.

(iv) Opportunity for use of skills and abilities.

\section{Employee's Training and Development}

According to Bateman and Snell (2011), training involves educating lower-level workers how to perform their present jobs, while development involves teaching managers and professional employees broader skills needed for their present and future jobs. Nabi et al. (2017:57) described training and development as "an educational process which involves the sharpening of skills, concepts, changing of attitude and gaining more knowledge to enhance the performance of employees". A study of public and private sector organizations in South Africa denoted training and development as motivational variables for employee's retention. The result delivered strong indication of a relationship between training and development and employee retention [Samuel \& Chipunza, 2009]. Kabungaide, Matilatshana and Ngirande (2013) found a significant friendly relationship between job satisfaction based on training and employee retention. Terera and Ngirande (2014) also found that there is 


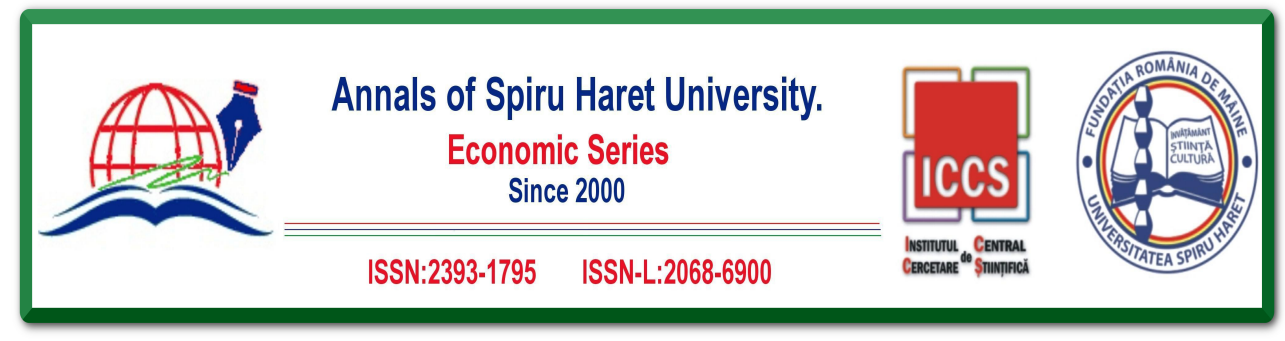

Issue 2/2019

positive correlation between job satisfaction and training which in turn helps in retaining employees. The following points may be considered under this category:

(i) Access to training and development programmes.

(ii) Equal chance for growth despite being female or male.

(ii) Changing of attitudes and gaining more knowledge.

\section{Job Security}

According to Singh and Jain (2013:107), job security is "an employee's confidence that they will keep their current job". Employees with a strong level of job security have a low likelihood of losing their job in the near future. Abegglen (1958), cited in Das and Baruah (2013), found during the study of Japanese workers that employment features like job security lead to high commitment, job satisfaction, as well as retention of employees in an organization. Study conducted by Davy, Kinicki and Scheck (1991) revealed that job satisfaction is the upshot of job security among employees. Certain employment opportunities implicitly have meliorated job security than others. In addition, job security is affected by the worker's performance, success of the business, and the current economic environment [Singh \& Jain, 2013]. The following points may be delineated under this category:

(i) Facility of transfer.

(ii) Accessible/reasonable target.

(iii) Leaves.

\section{Relationship with Immediate Boss}

A good working relationship with your immediate boos or superior is very important since, at every stage, you need his/her professional input, constructive criticism, and broad understanding [Singh \& Jain, 2013]. A great and supportive boss is identified as one of the top five reasons of employees' performance and retention [Bhatnagar, 2007]. Brunetto and Farr-Wharton (2002) stated that effective supervision of the immediate boss increases the level of job satisfaction in the public sector employees. Relationship with immediate boss is referenced as a significant factor of emotional commitment, job satisfaction and employee retention [Ahsana, Foonga, Alamb \& Gun-Fiea, 2013]. The following points may be delineated under this category:

(i) Relationship with immediate boss.

(ii) Fair treatment. 


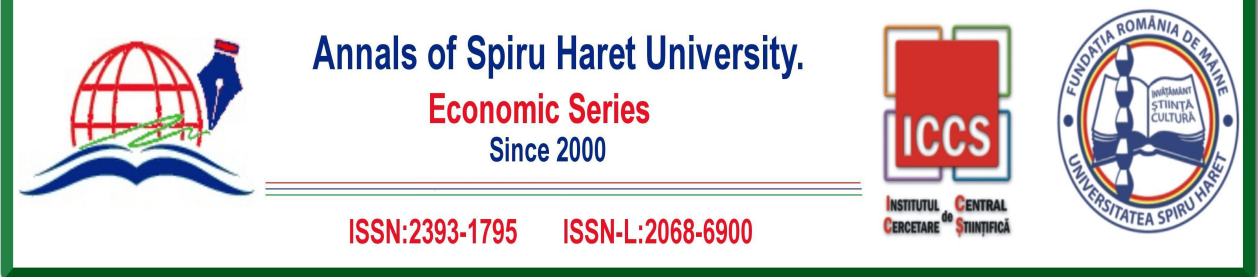

Issue 2/2019

(iii) Communication between employees and top management.

\section{Relationship with Co-workers}

It is an innate desire for human beings to interact with others. Thus, the existence of a group in the organization is a common knowledge. Isolated workers dislike their job [Singh \& Jain, 2013]. A good working relationship with co-workers increases employee's involvement which in turn influences employees' performance and therefore job satisfaction. Relationship with co-workers has uncommon influence on the job satisfaction of employees. The following points may be delineated under this category:

(i) Relationship with co-workers.

(ii) Need for affiliation.

(iii) Group cohesiveness.

\section{Leadership Styles}

If a form of leadership that is congruent to the needs of an organization is used, it will contribute to workers satisfaction. A supervisor or a manager could be employee centred or job centred. The employee centred behaviour, i.e. a leader that has a high concern for his/her subordinates, has been found to contribute more to worker's satisfaction. The following points may be delimitated under this category:

(i) Prefer democratic style of leadership.

(ii) Style of leadership.

(iii) Respect, friendship, and warmth relationship.

\section{The Job Itself}

Jobs that provide avenues for enhancing one's status and recognition contribute to job satisfaction. This implies jobs that are challenging and interesting which can enable the employee to see his/her potentials to the fullest. Job rotation, job enlargement and job enrichment are very useful in this regard. Therefore, factors such as job design, job rotation, job enlargement, and job enrichment are very important when putting into consideration the effects of job itself on employee job satisfaction. The following points may be delineated under this category:

(i) Job design.

(ii) Job rotation.

(iii) Job enlargement. 


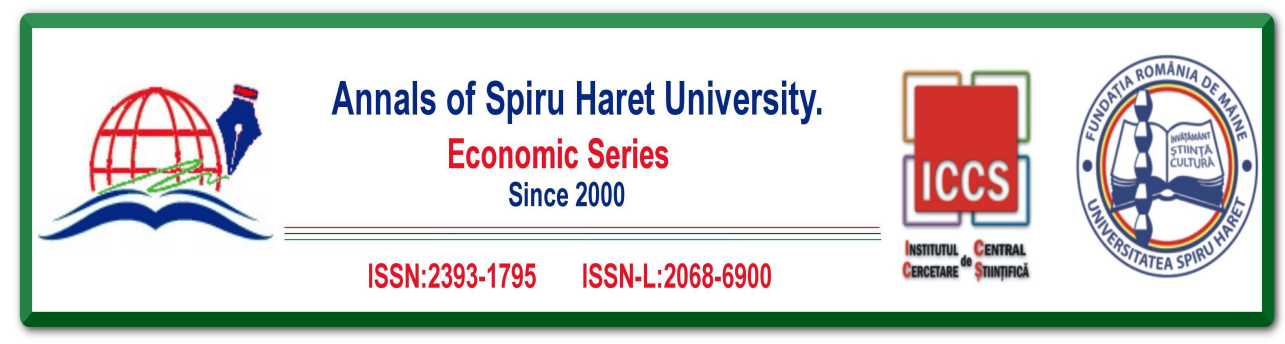

Issue 2/2019

(v) Job enrichment.

\section{Other Factors}

There are some other essential factors which affect the level of employee's job satisfaction in the organization. The following points may be delineated under this category:

(i) Encouragement and feedback.

(ii) Group outgoing (feel like a part of family).

(iii) Use of internet and other technology for doing job.

(iv) Flexible work arrangement.

(v) Employee empowerment.

\section{Employee Retention}

Employee retention problems are merging as the most critical workforce management challenges of the immediate future. Dutta and Banerjee (2014) posit that in near future, triumphant organizations will be those which adapt their organizational behaviour to the realities of the current work environment where longevity and success depend upon creativity, and flexibility. Therefore, the retention of talented employees is critical to the long-term health and success of an organization. Retaining the talented employees assures product sales, customer satisfaction, contented coworkers and reporting authority, effective progression planning and profoundly embedded organizational knowledge and learning [Ongori, 2007; Safdar, 2012; Dutta \& Banerjee, 2014; Ruchi \& Surinder, 2014; Shakeel \& But, 2015].

Employee retention is "a systematic endeavour by management to create and foster a workplace that encourages current employees to remain employed by having policies and practices in place that address their distinct needs" [Adegoke, 2013:101]. Das and Baruah (2013) has viewed retention as a procedure in which the employees are animated to remain with organization for the maximum period of time. Haider et al. (2015:64) were of the view that "employee retention consists of processes through which employees are encouraged to become part of the organization for a longer period of time until he/she gets retired or until the project gets completed". Healthfield (1995) stated that gifted and estimable employees are asset of an organization and that they are highly essential for the long-term growth and success of the business. Thus, it is necessary to retain the skilled employees not because of the costs incurred on them by employers, but also because the knowledge and skills 


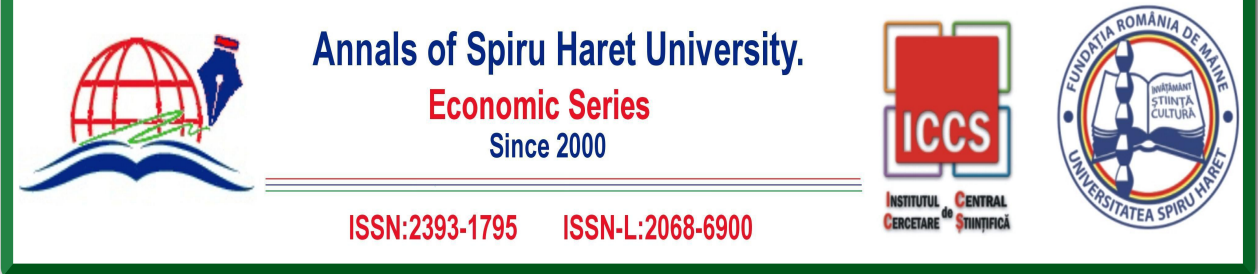

\section{Issue 2/2019}

of talented employees have become highly essential in gaining competitive advantage in today's business world.

Samule and Chipunza (2009:412) stated "that it is not only the private sector, but governments are also facing difficulty in retaining skilled employees. Private sectors managers admit this facts that retaining talented employees of the organization is the most difficult aspect of their job. Most of the time when these employees leave, they migrate to competing organizations with the knowledge and trade secrets acquired from their former employers, thus creating a critical situation for the former employers". This situation demands that management should identify the reasons for frequent change of employment by employees. Moreover, not few researchers have tried to answer the question as to what determines people's intention to quit by investigating antecedents of employees' intentions to quit. Until date, there has been little consistency in findings, which is partly due to the diversity of employed antecedents, including by researchers, and lack of consistency in their findings. Thus, there are various reasons why people quit from one organization to another. According to Armstrong (2009); Bateman and Snell (2011); Safder (2012); Haider et al. (2014); Azeez (2017), the potential reasons of an employee to quit his/her job can be amongst the following:

(1) More pay.

(2) Lack of challenge or growth.

(3) More security.

(4) Poor relationships with manager/team leader.

(5) Lack of trust in top management.

(6) Better working conditions.

(7) Lack of re-organization.

(8) Overall low job satisfaction

(9) Bullying or harassment.

(10) Personal - pregnancy, illness, etc.

(11) More opportunity to develop skills.

(12) Poor relationships with colleagues.

(13) Better prospects (career move).

Quitting of job appears to reflect significant workplace problems, rather than opportunities for advancement into better jobs. Employees' turnover disrupts teams, raises costs, reduces productivity, and results in lost knowledge. So, it is important for the management to realize the essential of employee's job satisfaction and 104 


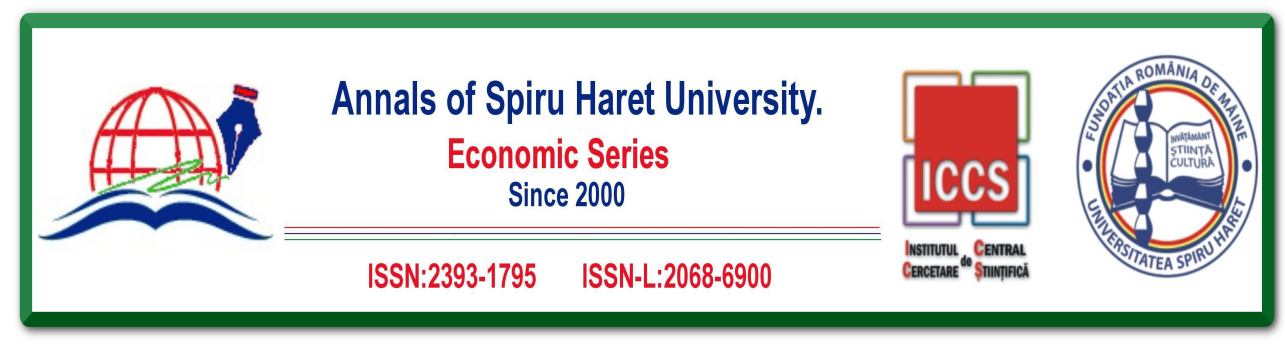

Issue 2/2019

retention. Jackson (1981) revealed in his study that high turnover is caused by unhappiness with work, inadequate compensation, unsafe and unhealthy conditions, unrealistic expectations, inappropriate processes or tools, and poor candidate screening. Price and Muller (1981) in their study on 1091 registered nurses in seven hospitals in United States found that job dissatisfaction determined actual turnover indirectly through its direct effects on turnover intentions. Employee turnover produced ethereal costs such as decline morale, and the interruption of social and communication patterns. All these factors indicate that there are no suitable management practices and policies on HR matters as such the employees decide to quit. Sunderji (2004) derived his conclusion based on Herzberg 1968's two factor theory, i.e., the motivating factors and satisfying factors. The main conclusion he made with the application of the two factor theory to employee turnover is that, if the employees are motivated and satisfied with their jobs, they will have no intention or reason to jump into another ship.

\section{Job Satisfaction and Employee Retention}

The idea of employee retention begun during 1970's and mid 1980's, when people and organizations became mindful of the importance of retaining the gifted employees and its advantages to the organization. Before 1970's, people join the organization to earn or meet their daily needs. However, the rapid growth in the industries with high competition among the competitors, compelled the top management and HR department to put in an extensive time, financial resources and effort in managing and retaining promising employees as a means of gaining competitive advantage among the organizations. Denton (2000) was of the view that employees who are happy and satisfied with their jobs are more devoted towards their work and always put in more effort to improve customer's satisfaction. Recichheld (1996) added to this view that there are three criteria that have impact upon how hard employees are working. They work hard when: (i) they have job pride, (ii) when they find their jobs interesting and meaningful, and (iii) when they are recognized for their work and benefit from the work they have accomplished. Herzberg (1968) affirms that providing chances for achievement; recognizing workers contributions; creating work that is rewarding and that matches the skills and abilities of the employees; giving as much responsibility to each team member as possible; providing opportunities to advance in the organization through internal promotions; offering training and development opportunities are the elements of satisfaction which increases employee retention. 


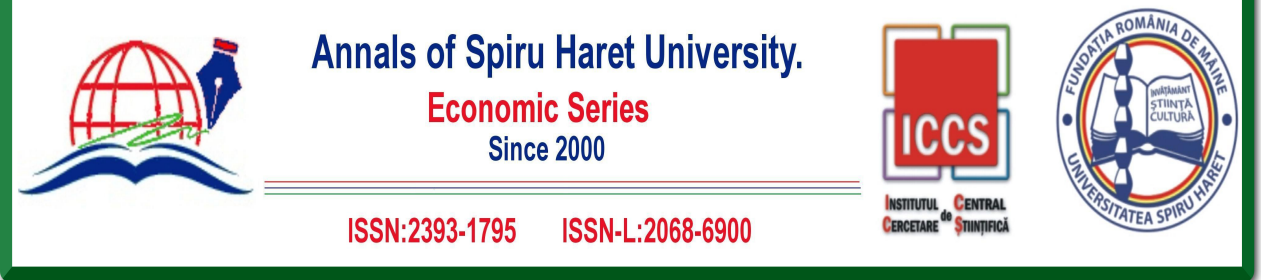

Issue 2/2019

According to Ishigaki (2004); Terera and Ngirande (2014); Azeez (2017); Ekwoaba and Ajibewa (2018), workforce are more satisfied when they feel that they are rewarded favourably for the work they do and the rewards are for genuine contributions to the organization and consistent with the reward policies. The reward may include a variety of benefits and perquisites other than monetary gains. Employees with higher job satisfaction are more dedicated to the organization, have higher retention rates and may tend to have higher productivity. Satisfied employees are more likely to perform beyond the call of duty to meet customer's needs and are higher motivated to work to the best of their ability. More importantly, satisfied employees remain in employment of the organization longer, resist competitive job offers, do not actively look for other employment, and recommend the organization to others as a good place to work. Recent studies have shown that managers are able to reduce unwanted voluntary turnover, because the most important factors driving employee satisfaction and commitment are largely within the direct control of the managers. These may include proving recognition, regular feedback and assuring fair compensation reflecting employee's contributions and value to the organization [Insight Link Communication, 2004; Eshiteti et al., 2013; Haider et al., 2015; Nabi et al., 2017; Okolie \& Omole, 2017].

Kaliprasad (2006) asserts that an organization's capacity to retain its employees completely depends upon it ability to manage them. He found out four interlinked processes that can be utilized for an effective HR system. These are: (i) the motivational process; (ii) the interaction process; (iii) the visioning process; and (iv) the learning process. Okpara (2004) holds that employee turnover is very costly to an organization in terms of monetary and customer satisfaction. Abbasi and Hollman (2000) assert that the cost of replacing an employee can be huge due to advertising and recruiting, lost of productivity, and time spent on training a new employee. This supports the assertion of Baker (2006) who posits that hiring new employees is far more difficult as well as more costly than to retain the current employees in the organization. Managing workforce retention requires paying attention to efficiency and equity. Accordingly, it is not enough for management policies to ensure high organizational productivity. Thus, employees equity perceptions are shaped by the perceived fairness and consistency in promotions and replacements within the organization. Wocke and Heymann (2012) added to this view that the cost of hiring new employee varies and it includes a wide variety of expenses such as advertisements, recruiters' salaries and reimbursements of candidates' expenses, and training of new employees.

106 


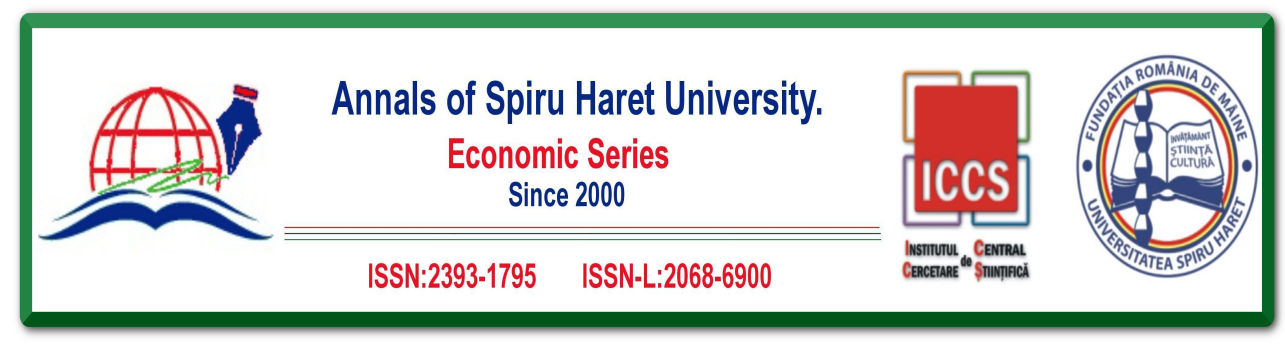

Issue 2/2019

Okolie and Omole (2017) hold that individual satisfaction, individual sense of attachment and realizing long-term personal goals are the factors of satisfaction which enhance organization's image and retention of talented employees. In a study by Parvin and Kabir (2011) it was found that satisfied employees tend to be more creative, committed, and productive to their employers. Job satisfaction not only ameliorates the retention of employees but also decreases the cost of hiring new employees. It is obvious, from the foregoing, that employee's job satisfaction derives employee retention and lack of job satisfaction contributes to poor employee retention. Therefore, the organization which encourages employee to stay in the organization for a longer period of time will definitely reap the benefit of increase productivity, enhance organizational image and retention of desirable employees and better teamwork.

\section{Theoretical Framework}

The theory guiding thus study is two-factor theory. The two-factor theory popularized by Herzberg (1968) was adopted as a theoretical approach underpinning the study to better comprehend employees' attitudes and motivations to remain in or leave an organization. According to Herzberg (1968), what do employees want from their jobs? Do they want just a higher salary? Or do they want security, good relationships with co-workers, opportunities for growth and advancement or something else altogether? These are important questions to better understand employee attitudes and motivation. Herzberg (1968) two-factor theory distinguished between two broad categories of factors in an employee's workplace that caused satisfaction or dissatisfaction. The first categories, hygiene factors, are characteristics of the workplace: organization policies, working conditions, pay, supervision, relationships with co-workers, relationships with management, etc. These factors can make employees unhappy if they are poorly managed. If they are well managed, and viewed as positive by employees, the employees will no longer be dissatisfied. However, no matter how good these factors are, they will not make employees truly motivated and satisfied to do a good job.

According to Herzberg, the fundamental to true job satisfaction and motivation to perform lies in the second category: the motivators. The motivators described the job itself, that is, what people do at work. Motivators are the nature of the work itself, the actual job responsibilities, opportunity for personal growth and recognition, and the feelings of achievement the job provides. When these factors are present, jobs are 


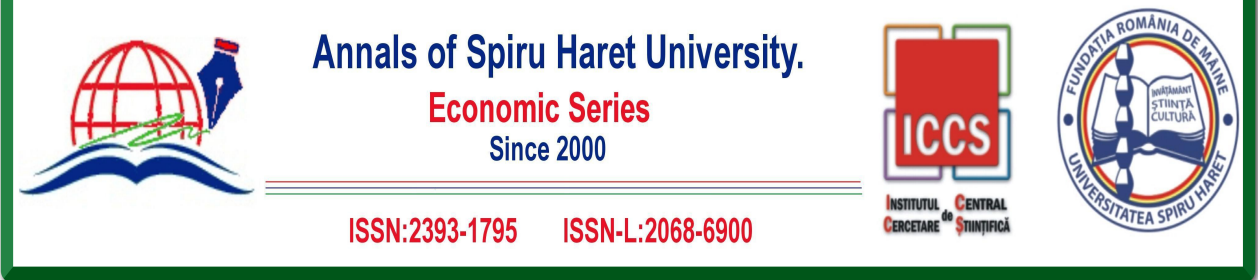

Issue 2/2019

presumed to be both satisfying and motivating for most people. To apply Herzberg's perspective on motivation in a workplace, one needs to adopt a two stage procedure to motivate people to perform. Firstly, one needs to eliminate the dissatisfactions that workers are experiencing and secondly, as well, the need to help an employee find satisfaction. When these are successfully done, employee retention is guaranteed. This theory was relevant to this study in that it aims at stressing the importance for organization to have both hygiene factors and motivation factors to keep their employees satisfied as well as to remain with the establishment for a longer period of time. Motivation factors are often said to lead to high retention, but the absence of hygiene factors may result in increased employee turnover [Coetzee \& Schreuder, 2013].

Herzberg's theory has been criticized by many scholars because the specifics of his theory do not hold up to scientific scruting. In spite of the criticisms, the Herzberg two-factor theory continues to thrive because he made several very important contributions. Firstly, Herzberg's theory highlights the important distinction between extrinsic rewards (from hygiene factors) and intrinsic rewards (from motivation factors). Secondly, it reminds managers not to count solely on extrinsic rewards to motivate employees but to focus on intrinsic rewards as well. Thirdly, it sets the stage for later theories, such as the Hackman and Oldham model, that explain more precisely how managers can enrich people's jobs. Fourthly, it is easy to understand and seems to be based on 'real life' rather than academic abstractions and it is also in agreement with a fundamental belief in the dignity of labour and the protestant ethic - that work is good in itself. As a result, Herzberg had immense influence on the job enrichment movement, which sought to design jobs in a way that would maximize the chances to obtain intrinsic satisfaction from work and thus enhances the quality of working life.

\section{Employee Retention as Strategic HR Imperative}

"In today's versed economy, employees are looking for opportunities to learn and enhanced their skills and to have an open value for imaginations, ideas and creativity; top management interest in employee well-being; and to work for an organization with a reputation as a good employer" [Susi \& Jawaharrani, 2010: 474]. Employee retention starts at the top. Sourcing, hiring, and retaining talented employees are the responsibility of the organization's governing board and HR department. Securing and retaining skilled employees' demand focused, recognized, and comfortable policies 108 


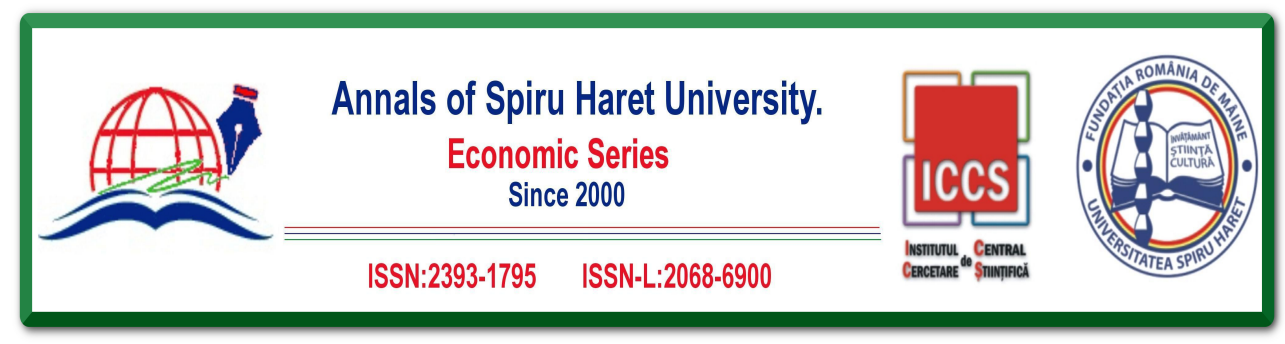

Issue 2/2019

and procedures that make retention a prime management outcome. Gberevbie (2008) posits that if suitable employee retention strategies are followed and implemented by organizations, employees will surely remain and work for the successful accomplishment of organizational goals. He further argued that an organization's inability to develop and implement strategies capable for recruiting suitable employees and retaining them to accomplish organizational goals is one of the major challenge facing organizations in the area of performance. In the view of Das and Baruah (2013), the HR department plays an active role in employee betterment. This shows that it is not just retention of employees but also retention of valued skills. Therefore, the HR manager or department must know how to attract and retain skilled employees because these are people who can make or mar the organization's goodwill [Wisnefski, 2008; Safdar, 2012; Haider et al., 2015].

Research shows that organizations that provide a workplace culture with the psychological conditions of meaningfulness (job enrichment, work-role fit), safety (supportive management and co-workers), and availability (resources available) are more likely to have engaged and committed employees and therefore employee retention [Messmer, 2000; Dutta \& Banerjee, 2014; Ruchi \& Surinder, 2014; Terera \& Ngirande, 2014; Haider et al., 2015]. Securing and retaining talented employees should become a critical part of HR policy and strategy if it is to truly get the best from the employees without leaving them burnt-out, unsatisfied, and unfulfilled. Moreso, after recruiting the right people, it is HR's most essential role to take responsibility for the success of their employees including leading employees towards performance goals and target [Yusoff, Khan, Mubeen \& Azam, 2013]. Successful employee retention does not rely on a single strategy. Thus, strategies of retention, which are based on developing human resource management systems such as enhancing communication process and their HR policies and practices, should be implemented in order to avoid high rate of attrition and its negative consequences. In short, more effort should be exerted to improve employee retention by taking into consideration the many factors such as better recruitment, compensation practices, training and career development, work-life balance, organizational commitment, job security, counselling of leavers, policies for turnover, job flexibility, working environment, skill recognition and respect, review of job content, participation in decision-making, and promotion and organizational support. Needless to say that, these endeavours should be carried out by HR professionals. 


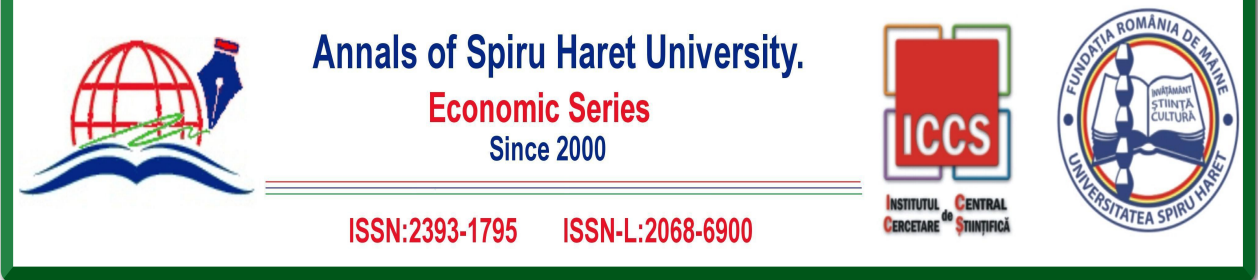

Issue 2/2019

\section{Conclusion}

Long-run success and health of any organization depends upon the retention of skilled employees. They are the most vital and dynamic resources of any organization as the knowledge and skills of employees have become highly important in gaining competitive advantage in today's business environment. Hence keeping a well trained, skilled, and contended workforce can lead an organization to greater heights while the lack of it can hamper its growth badly. Besides, it has been observed that employee turnover is becoming a challenge which costs a lot of efforts, money, and energy. So, every resignation saved is money earned. Also, every organization should develop strategies that strengthen the work environment and increases the employee's morale and employee's job satisfaction to enhance employee retention, which ultimately results in high profits, customer satisfaction, as well as customer retention. Therefore, if the above mentioned factors exist in the organization, it will not only help to attract new employees into the organization but will also lead to the retention of the existing ones. The main role of HR, therefore, is to understand the critical issues of employee retention, integrate them into the organization's HR policy, and support employee retention programmes.

\section{Policy Recommendations}

Arising from the foregoing, this study recommends that management should always provide an enabling environment that protects the health and safety of employees and minimizes stress. Evolve a climate of trust by being honest with employees, treating them fairly, justly and consistently, keeping its words, and showing willingness to listen to the comments and suggestions made by employees during processes of consultation and participation. Improve employee engagement, i.e., identification of employees with the job they are doing, through job design processes that aim to create higher levels of job satisfaction. Declare a policy of employment securing and ensure that steps are taken to avoid involuntary turnover. Protect employees against harmful practices at work, e.g., bullying, harassment, and discrimination. Furthermore, recruitment and selection must be done scientifically with the objective of keeping employees. Bearing in mind that employees are the long-term investments in an organization, as such management should encourage job redesign, task autonomy, task significance and task identity to create higher levels of job satisfaction and therefore employee retention. 


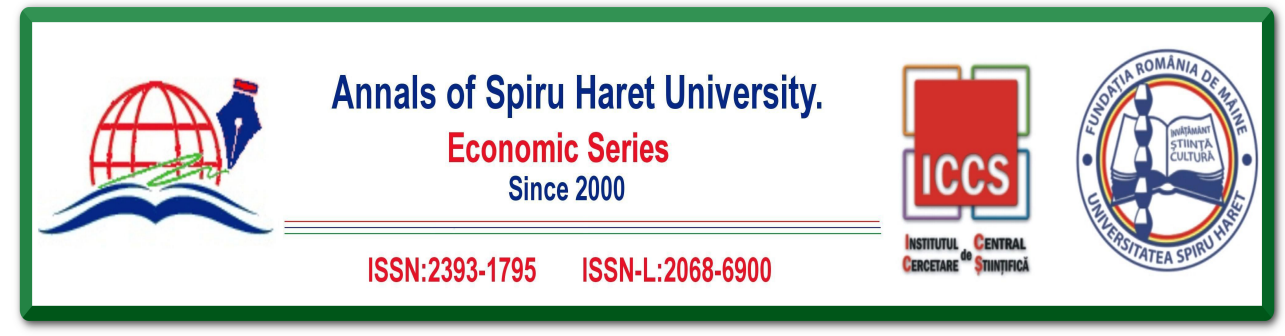

Issue 2/2019

\section{References}

[1] Abbasi, M.S., \& Hollman, K.W. (2000). "Turnover: The real bottom line." Publish Personnel Management, 2(3), 333-342.

[2] Adegoke, A.A. (2013). Advanced human resource management II. Lagos: Chartered Institute of Personnel Management of Nigeria.

[3] Ahsana, N., Foonga, Y.P., Alamb, S.S., \& Gun-Fiea, D.Y. (2013). "Relationship between retention factors and effective organizational commitment among knowledge workers in Malaysia." Journal of Business, Economic and Management, 14(5), 93-122.

[4] Anyim, C.F., Ikemefuna, C.O., \& Mbah, S.E. (2011). "Human resource management challenges in Nigeria under a globalized economy." International Journal of Economics and Management Sciences, 1(4), 1-11).

[5] Armstrong, M. (2009). Armstrong's handbook of human resource management practice. London: Kogan page.

[6] Azeez, S.A. (2017). "Human resource management practices and employee retention: A review of literature." Journal of Economic, Management and Trade, 18 (2), 1-10.

[7] Baker, E. (2006). The human factor. CIO Insingt, 73, 40-50.

[8] Bartlett, C., \& Ghoshal, S. (2013). "Building competitive advantage through people." Sloan Mgmt. Rev., 43(2), 16-25.

[9] Bateman, T.S., \& Snell, S.A. (2011). Management: Leading \& collaborating in a competitive world. United States: McGraw-Hill.

[10] Bhatnagar, J. (2007). "Talent management strategy of employee engagement in Indian ITES employees: Key to retention.” Employee relations, 29(6), 640-663.

[11] Brunetto, Y., \& Farr-wharton, R. (2002). "Using social identity theory to explain the job satisfaction of public sector employees." International Journal of Public Sector Management, 15 (97), 534-551.

[12] Coetzee, M., \& Schreuder, D. (2013). Personnel psychology: An applied perspective. South Africa: Oxford University Press.

[13] Das, B.L., \& Baruah, M. (2013). "Employee retention: A review of literature." IOSR Journal of Business and Management, 14(2), 8-16.

[14] Davy, J., Kinicki, A., \& Scheck, C. (1999). "Developing and testing a model of survivour responses to layoffs." Journal of Vocational Behaviour, 38, 302-317.

[15] Denton, J. (2000). "Using web-based projects in a systems design and development course." Journal of Computer Information System,4(3), 85-87.

[16] Dutta, A.B., \& Banerjee, S. (2014). "Study of employee retention." International Journal of Business Management \& Research, 4(1), 83-88.

[17] Ejiogu, A. (1978). Behavioural decisions in organization. Scotland: Fortesman Company ltd. 

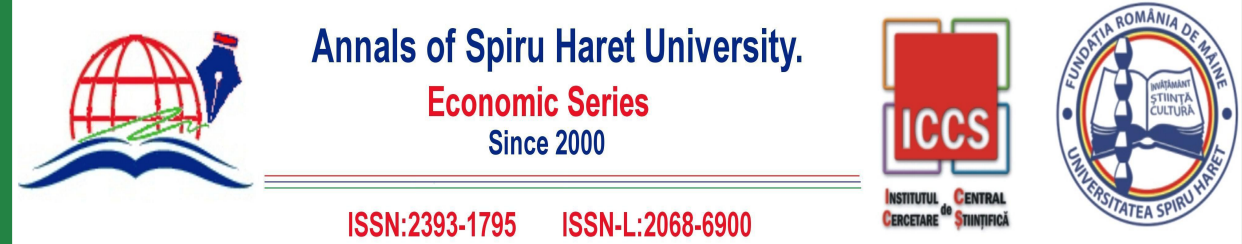

Issue 2/2019

[18] Ekwoaba, J.O., \& Ajibewa, S. (2018). Advanced human resource management 2. Lagos: Chartered Institute of personnel management of Nigeria.

[19] Ellickson, M.C., \& Logsdon, K. (2002). "Determinants of job satisfaction of municipal government employees." Public Personnel Management, 31(3), 343-358.

[20] Eshiteti, S.N., Okaka, O., Maragia, S.N., Odera, O., \& Akerele, E.K. (2013). "Effects of succession planning programs on staff retention." Mediterranean Journal of Social Sciences, 4 (6), 157-162.

[21] Gberevbie, D.E. (2008). Staff recruitment, retention strategies and performance of selected public and private organizations in Nigeria. Ph.D. Thesis, Govenant Uni., Ota.

[22] Hairder, M., Rasli, A., Akhtar, C.S., Yusoff, R.B.M., Malik, O.M., Aamir, A., Arif, A., Naveed, S., \& Tariq, F. (2015). "The impact of human resource practices on employee retention in the telecom sector." International Journal of Economics and Financial Issues, 5, 63-69.

[23] Healthfiled, S.M. (1995). Top ten ways to retain your great employees. Retrieved from htt://www.humanresources.about.com/od/retention/a/more_retention.htm.

[24] Herzberg, F. (1968). Work and the nature of man. London: World publishers.

[25] Hytter, A. (2007). "Retention strategies in France and Sweden." The Irish Journal of Management, 28(1), 59-89.

[26] Insightlink Communication (2004). The state of economy satisfaction. Retrieved from http://www.inmsightlink.com/employeesatisfaction.html.

[27] Jackson, M. (1981). Personnel. London: Heinemann Publishers.

[28] Kabungaidze, T., Mahlatshana, N., \& Ngirande, H. (2013). "The impact of job satisfaction and some demographic variables on employee turnover intentions." International Journal of Business Administration, 4(1), 53-65.

[29] Kaliprasad, M. (2006). "The human factor: Attracting retenting and motivating capable people." Cost Engineering, 48 (6), 20-26.

[30] Khan, A.H., \& Aleem, M. (2014). "Impact of job satisfaction on employee turnover: An empirical study of autonomous medical institutions of Pakistan." Journal of Internal Studies, 7(1), 122-132.

[31] Lane, K.A., Esser, J., Holte, B., \& McCusker, M.A. (2010). "A study of nurse faculty job satisfaction in community colleges in Florida." Teach. Learn. Nurs. 5, 16-26.

[32] Lease, S.H. (1998). "Annual review, 1993-1997: work attitudes and outcomes." Journal Vocational Behaviour, 53(2). 154-183.

[33] Messmer, M. (2000). "Orientations programs can be key to employee retention." Strategic Finance, 81 (8), 12-15.

[34] Miller, N., Erickson, A., \& Yust, B. (2001). "Sense of place in the workplace: The relationship between personal objects and job satisfaction and motivation." Journal of Interior Design, 27(1), 35-44. 

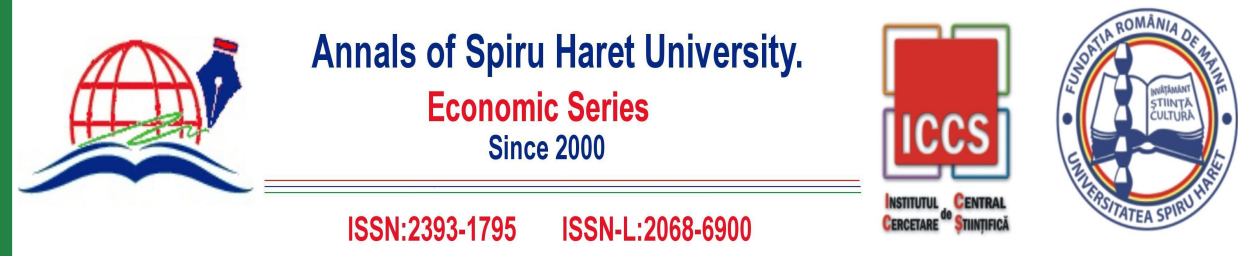

Issue 2/2019

[35] Mulinge, M., \& Muller, C.W. (1998). "Employee job satisfaction in developing countries: The case of Kenya." World Dev. 26(26), 2181-2199.

[36] Nabi, M.N., Ahmed, A.A.J., \& Rahman, M.S. (2017). "The empirical study on human resource management practices with special reference to job satisfaction and employee turnover at investment corporation of Bangladesh." Human Resource Management Research, 7(1). 54-64.

[37] Ohadinma, D.C. (2005). Management periscope: Periscoping issues in management and business. Owerri: Bon Publications.

[38] Okolie, U.C., \& Omole, O.G. (2017). 'Impact of teamwork on employees' job satisfaction and performance among polytechnic teachers: A case of Auchi polytechnic, Auchi, Edo State." Human Resource Management Journal, 9(1), 56-72.

[39] Okolie, U.C., Igbo, A.V., \& Omole, O.G. (2017). "Impact of work-life balance on employee job attitudes: A review." Journal of Management and Corporate Governance, 9(1), 71-93.

[40] Okpara, J.O. (2004). "Personal characteristics as predictors of job satisfaction: An explora-tory study of IT managers in a developing economy." Information Technology and People, 17(3), 327-338.

[41] Ongori, H. (2007). "A review of the literature on employee turnover." African Journal of Business Management, 2(9), 49-54.

[42] Osteraker, M.C. (1999). "Measuring motivation in a learning organization." Journal of workplace Learning, 2(3), 18-25.

[43] Parvin, M.M., \& Kabir, M.M.N. (2011). "Factor affecting employee job satisfaction of pharmaceutical sector." Australian Journal of Business and Management Research, 1(9), 113-123.

[44] Price, J., \& Muller, C. (1981). "A causal model of turnover of nurses." Academy of Management Journal, 24 (3), 543-565.

[45] Reilly, C.R. (1991). "Organizational behaviour." Annual Review of Psychology, 5, 427-458.

[46] Robbins, S.P., Judge, T.A., \& Sanghi, S. (2009). Organizational behaviour. New Delhi: Prentice Hall.

[47] Ruche, J. (2014). "Effect of job satisfaction on employee retention in banking sector: A cast study of ICICI bank in Jaipur city." International Journal of Scientific Research and Reviews, 3(2), 95-110.

[48] Safdar, M.R. (2012). "Employee turnover and retention strategies: An empirical study of public sector organizations of Pakistan." Global Journal of Management and Business Research, 12(1), 83-89.

[49] Samuel, M.O., \& Chipunza, C. (2009). "Employee retention and turnover: using motivational variables as a panacea." African Journal of Business Management, 398), 410-415. 


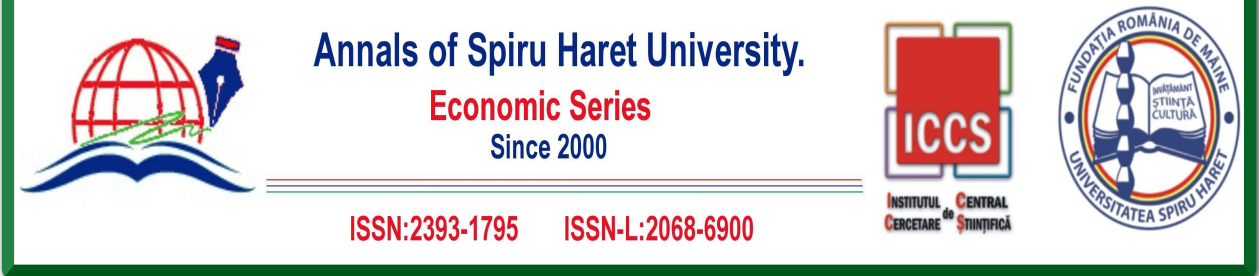

\section{Issue 2/2019}

[50] Shakeel, N., \& But, S. (2015). "Factors influencing employee retention: An integrated perspective." Journal of Resource Development and Management, 6, 32-49.

[51] Singh, J.K., \& Jain, M. (2013). "A study of employees' job satisfaction and its impact on their performance." Journal of Indian Research, 1(4), 105-111.

[52] Spector, P.E. (1997). Job satisfaction: Application, assessment, causes, and consequences. Thousand Oaks, CA: Sage.

[53] Stein, N. (2000). "Winning the wear to keep top talent: yes you can make your workplace invincible." Fortune, 41(11), 132-138.

[54] Sunderji, M.G. (2004). "Employee retention and turnover: The real reasons employees stay or go." FMI Journal, 15(2), 37-48.

[55] Susi, S., \& Jawaharriani, K. (2010). "Work-life balance: the key driver of employee engagement." Asian Journal of Management Research, 2(1), 474-483.

[56] Terera, S. R., \& Ngirande, H. (2014). "The impact of training on employee job satisfaction and retention among administrative staff members: A case of a selected tertiary institution." J.SOC. SCI, 39(1),

[57] Umukoro, N. (2005). Principles of management and behavioural sciences. Benin: Mindex publishing ltd.

[58] Unugbro, A.O. (2006). Advanced management. Benin: Mindex Publishing ltd.

[59] Vidal, M.E.S., Valle, R.S., \& Aragon, B.M.I. (2007). "Antecedents of repatriates job satisfaction and its influence on turnover intentions: Evidence from Spanish repatriated managers." Journal of Bus. Res., 60, 1272-1281.

[60] Wanous, J.P., \& Lawler, E.E. (1972). "Measurement and meaning of job satisfaction." Journal of Applied Psychology, 5, 95-105.

[61] Wells, M., \& Thelen, L. (2005). "What does your workplace say about you? The influence of personality, status and workplace on personalization." Environment and Behaviour, 3, 300-321.

[62] Wisnefski, M. (2008). "Employee retention in the new millennium." Business Services, 16(3), 465-507.

[63] Wocke, A., Heymann, M. (2012). "Impact of demographic variables on voluntary labour turnover in South Africa." The International Journal of Human Resource Management, 23(6), 3479-3494.

[64] Yusoff, R.M., Khan, F., Mubeen, A., \& Azam, K. (2013). "A study about factors influencing the university performance." Journal of Teknologi, 64 (2), 146-149.

[65] Zineldin, M. (2000). Total relationship management. Laund: Student litterateur. 